\title{
Social Skills, Social Support and Well-Being in Adolescents of Different Family Configurations $^{1}$
}

\author{
Vanessa Barbosa Romera Leme ${ }^{2}$ \\ Universidade Salgado de Oliveira, \\ Niterói-RJ, Brazil
}

\author{
Zilda Aparecida Pereira Del Prette \\ Universidade Federal de São Carlos, \\ São Carlos-SP, Brazil
}

\author{
Susana Coimbra \\ Universidade do Porto, Porto, \\ Portugal
}

\begin{abstract}
There is no consensus in the literature regarding the influence of family configuration on the psychological well-being of adolescents. Based on the perception of adolescents, this study evaluates the influence of family configuration, social skills and social support appraisals as potential predictors of adolescent psychological well-being. The participants were 454 adolescents aged between 13 and 17 years from nuclear, separated and remarried families. The adolescents were students in the first and second years of public high school. The data were collectively obtained in the classroom using the Social Skills Inventory for Adolescents, the Social Support Appraisal Scale and the Psychological Well-being Scale. The results indicated that family configuration is not associated with the psychological well-being of adolescents. The social skills of empathy, self-control, civility, social resourcefulness and affective approach as well as the social support appraisals from friends and family were the best predictors of adolescent psychological well-being. The implications of the results are discussed with respect to future research and interventions.
\end{abstract}

Keywords: social skills, social perception, subjective well-being, adolescence

\section{Habilidades Sociais, Apoio Social e Bem-Estar de Adolescentes de Diferentes Configurações Familiares}

\begin{abstract}
Resumo: Não existe consenso na literatura quanto às influências da configuração familiar no bem-estar psicológico de adolescentes. A partir da percepção de adolescentes, este estudo avaliou a influência da configuração familiar, habilidades sociais e percepção de apoio social como possíveis variáveis preditoras do seu bem-estar psicológico. Participaram 454 adolescentes, na faixa etária entre 13 e 17 anos, de famílias nucleares, monoparentais e recasadas que frequentavam o Ensino Médio. Os participantes responderam coletivamente, em sala de aula, ao Inventário de Habilidades Sociais para Adolescentes, à Escala de Percepção de Apoio Social e à Escala de Bem-estar Psicológico. Os resultados indicaram que a configuração familiar não está associada ao bem-estar psicológico dos adolescentes. As habilidades sociais de empatia, autocontrole, civilidade, desenvoltura social e abordagem afetiva e a percepção de apoio dos amigos e da família foram os melhores preditores do bemestar psicológico dos adolescentes. Discute-se as implicações dos resultados para novas pesquisas e intervenções.
\end{abstract}

Palavras-chave: habilidades sociais, percepção social, bem-estar subjetivo, adolescência

\section{Habilidades Sociales, Apoyo Social y Bienestar de Adolescentes de Diferentes Configuraciones Familiares}

\begin{abstract}
Resumen: No hay consenso en la literatura sobre la influencia de la configuración familiar en el bienestar psicológico de los adolescentes. Con base en la percepción de los adolescentes, este estudio evalúa la influencia de la configuración familiar, habilidades sociales y apoyo social percibido como posibles predictivos de su bienestar psicológico. Participaron en el estudio 454 adolescentes de edades comprendidas entre 13 y 17 años de las familias tradicionales, familias con madres divorciadas y familias reconstituidas, en el primer y segundo año de la escuela secundaria. Los participantes respondieron colectivamente en el aula al Inventario de Habilidades Sociales para Adolescentes, la Escala de Apoyo Social Percibido y la Escala de Bienestar Psicológico. El resultado indicó que la configuración familiar no se asocia con el bienestar psicológico de los adolescentes. Las habilidades sociales de empatía, autocontrol, civilidad, inventiva social y aproximación afectiva, así como la percepción de apoyo de amigos y familia fueron los mejores predictores del bienestar psicológico de los adolescentes. Se discuten las implicaciones de los resultados para la investigación y las intervenciones en psicología.
\end{abstract}

Palabras clave: habilidades sociales, percepción social, bienestar subjetivo, adolescencia

\footnotetext{
1 Support: São Paulo Research Foundation (FAPESP - Protocol no. 2011/05321-4).

${ }^{2}$ Correspondence address:

Vanessa Barbosa Romera Leme. Programa de Pós-Graduação em Psicologia da Universidade Salgado de Oliveira. Av. Marechal Deodoro, 217, $2^{\circ}$ andar. Centro. CEP 24030-060. Niterói-RJ, Brazil. E-mail: vanessaromera@gmail.com.
}

Marital separation and/or the remarriage of parents can result in a considerable number of stress inducers in family members, particularly during the first two years following these family transitions (Amato \& Anthony, 2014; Levin, Kirby, \& Currie, 2012; Wallerstein, Lewis, 
\& Rosenthal, 2013). These stress inducers include changes in the family routine as a result of the change of residence and school and changes in the family configuration (such as the presence of half-siblings). Because all of these changes may result in adaptation challenges (Amato \& Anthony, 2014; Mota \& Matos, 2011), marital separation and parental remarriage are believed to be chronic or recurring conditions of unpredictability in the family environment that may adversely affect, above all, the well-being of the children (Amato \& Anthony, 2014; Bizarro, 2010; Musick \& Meier, 2010). Based on a literature review, Anderson and Grenne (2013) and Wagner, Tronco and Armani (2011) argued that the emotional symptoms and challenges of ex-spouses and their children must in fact occur because when families that have and have not experienced marital dissolution are compared the reviewed studies were unable to separate the effect of potential confounding variables that may affect well-being, such as depression, economic difficulties, behavioral problems or learning difficulties. A related factor that can affect the well-being of children is the social skills deficits (Sá, 2012; Sarkova et al., 2013). The literature also describes studies on the influence of marital separation and/or remarriage in parenting practices, which indirectly affects the well-being of the children (Hetherington, 2003; Wallerstein et al., 2013). Other studies found that the wellbeing of adolescents from families that experienced marital separation and the subsequent remarriage of the parents was not associated with the type of family but with the quality of the relationships among family members (Fernandes, 2007; Joronen \& Astedt-Kurki, 2005). These results suggest the multidetermined nature of psychological well-being, which is a multidimensional state (i.e., it involves cognitive, affective and behavioral components) and multifactorial (i.e., it results from the confluence of several internal and external factors that affect the individual). Thus, it is necessary to continue to investigate the impact of the separation and remarriage of parents on the well-being of children.

The well-being of adolescents is an important internal indicator of adjustment after marital separation and/or the remarriage of parents (Amato \& Afifi, 2006). This study investigated psychological well-being as conceived by Ryff (1989), which refers to a set of psychological capabilities and resources at the disposal of the individual that are used to address the challenges that occur throughout life. Scholars have noted that little attention has been paid to the positive aspects of the development of family members after marital separation and/or remarriage, which may occur as a result of these family transitions (Greeff \& Du Toit, 2009; Mota \& Matos, 2011). Thus, this study focuses on the resources and contexts of adolescents that may signal processes of adaptation and/or personal growth when faced with marital separation and parental remarriage (Mota \& Matos, 2011). Additionally, few studies have examined from the child's perspective the variables that are related to positive development and that can contribute to the prevention of emotional and behavioral challenges, such as the ability to establish positive relationships and the availability of coping skills when faced with stressful events (Oliveira, Siqueira, Dell'Aglio \& Lopes, 2008). Thus, social skills and social support appraisals are noteworthy among the factors that are listed in the literature as directly or indirectly affecting the well-being of adolescents from different types of family.

Various studies have found significant positive associations between a sound set of social skills and the well-being of adolescents from different types of family (Sá, 2012; Sarkova et al., 2013). According to Z. Del Prette and A. Del Prette (2010), social skills refers to the diverse set of behaviors of a person that can contribute to social competence, which results in healthy, productive relationships. For A. Del Prette and Z. Del Prette (2009), refusing requests without jeopardizing the relationship and establishing loving relationships are examples of the social skills required in the new interpersonal and academic tasks that are presented to the adolescent. Among these skills, according to Falcone et al. (2008), empathy has received prominence in the literature because it is believed to be a social communication skill that involves a subjective process in which the individual experiences and shares positive and negative emotions. Thus, empathy would be an important interpersonal skill in the lives of adolescents who experience changes in family configuration and require a better understanding of the needs of family members. Similarly, the empathy of others toward the adolescents who experience changes in family configurations is important. Regarding family transitions, various studies have indicated that the separation and/or remarriage of parents can negatively influence the social skills of children (Hamama \& Ronen-Shenhav, 2012; Hetherington, 2003). However, Ruschena, Prior, Sanson, and Smart (2005) found no negative associations between family transitions and the social skills of adolescents. This result suggests that a rich repertoire of social skills could foster resilience in the adolescent faced with family disruptions and other difficult life situations or related to their own development processes. Thus, the literature suggests that it is necessary to further investigate the influence of separation/remarriage of parents on the social skills of children during adolescence.

In recent years, social support has been a frequent research focus because it is considered to be an important external mechanism of protection against possible obstacles by which an individual can cope with the changes inside and outside the family environment (Aragão, Vieira, Alves, \& Santos, 2009; Gonçalves, Pawlowsk, Bandeira, \& Piccinini, 2011). However, few studies have sought to demonstrate the positive relationship between social support and well-being during adolescence (Casas et al., 2007; Sarriera, Abs, Casas, $\&$ Bedin, 2012). In the literature, social support is presented as a non-consensual, broad and diverse concept in theoretical and operational terms (Gonçalves et al., 2011). This study adopted the concept of social support appraisals as defined 
by Vaux et al. (1986) as the manner in which an individual perceives to be received and supported by significant others, such as family members, friends and teachers.

Family transitions can result in changes in social support from family members, which can modify spousal, parent-child and intra-sibling interaction (Amato \& Anthony, 2014; Hetherington, 2003; Wallerstein et al., 2013). Tomcikova, Geckova, Orosova, van Dijk, and Reijneveld (2009) demonstrated that marital separation was associated with lower levels of social support appraisals from family and lower levels of adolescent well-being. Thus, researchers have found that adolescents from families who have experienced marital separation and/or parental remarriage tend to experience less closeness and family support as a result of decreased parental monitoring (typically from the spouse with custody), increased conflict between parents and other related problems. Consequently, as a result of increased instability in the family environment (Cavanagh, Crissey, \& Raley, 2008; Ivanova, Mills, \& Veenstra, 2011) and less parental supervision (Friedlander, Connolly, Pepler, $\&$ Craig, 2007), the children may more easily and sooner engage in romantic and sexual relationships (Cavanagh et al., 2008) and manifest internalizing and externalizing behavioral problems (Hetherington, 2003; Vanassche, Sodermans, Matthijs, \& Swicegood, 2014). In addition, the romantic relationships of adolescents may be a way to escape the unstable family environment and provide comfort and warmth (Cavanagh et al., 2008; Ivanova et al., 2011).

However, results from longitudinal studies contradict these findings and demonstrate that family configuration does not influence the decision of adolescents to initiate sexual life (Pearson, Muller, \& Frisco, 2006) or the quality of their romantic relationships (Valle \& Tillman, 2014). In support of the hypothesis that family transition is not in itself a negative life event, other studies have found that family configuration does not influence the perceived social support (Pérez Milena et al., 2007). In addition, perceived social support has been positively associated with higher levels of problem solving, coping and communication skills in adolescents who belong to divorced families (Shin, Choi, Kim, \& Kim, 2010).

Although parental separation and remarriage may affect social support from other environments outside the family (Hamama \& Ronen-Shenhav, 2012; Nomaguchi, 2008), studies have indicated that the presence of friends and good relationships with teachers can function as protective factors for adolescents who experience parental marital separation (Greeff \& Du Toit, 2009). However, little attention has been paid to extra-familial social support (i.e., support from teachers, friends and significant others) for adolescents who have experienced family transitions. Thus, based on the perception of adolescents who belong to different family configurations, this study aimed to investigate the influence of family configuration, social skills and social support appraisal as potential predictors of adolescent psychological well-being. Based on the literature, it is hypothesized that social skills and social support appraisals would have a greater predictive effect than family configuration on the psychological well-being of adolescents.

\section{Method}

\section{Participants}

A predictive correlational study was conducted using a cross-sectional design and a convenience (non-probability) sample of 454 adolescents (204 from nuclear families, 143 from separated families and 130 from remarried families). The sample was $53.7 \%$ female and consisted of students in the first and second years of high school from three public schools in a city in the state of Minas Gerais. The participants were between the ages of 13 and 17 years old $(M=15.33, S D=.83)$. According to data from the Brazilian Association of Research Companies [Associação Brasileira de Empresas e Pesquisas - ABEP] (2011), the majority of adolescents in this study belonged to Class B1 (28.4\%) and class B2 (41.4\%), whereas $21.6 \%$ belonged to Class C, $7.5 \%$ to Class A2, $0.4 \%$ to Class D and $0.4 \%$ to Class A1. The sample size was determined to suit multiple linear regression analysis, which according to Marôco (2011) must contain at least 30 subjects for each independent variable. The distribution of adolescents in the groups was balanced. Based on the information provided by the adolescents (such as the marital status of their parents and the duration of the marital union and with whom they resided), inclusion criteria employed in the literature (Hetherington, 2003) were used to define nuclear, separated and remarried families as well as the time since marital separation or remarriage as follows: (a) Nuclear families: when the biological mother of the adolescent cohabited in a civil union or by consensus with the biological father of the adolescent, (b) Separated families: when the adolescent's mother did not cohabit with the adolescent's father or with another partner and was separated for at least two years, (c) Remarried families: when the biological mother of the adolescent cohabited with another partner who was not the biological father of the adolescent and cohabited in a civil union or by consensus for at least two years with another partner.

\section{Instruments}

The Social Skills Inventory for Adolescents (Inventário de Habilidades Sociais para Adolescentes - IHSA-Del-Prette) (A. Del Prette \& Z. De Prette, 2009) evaluates the social skills of adolescents based on their self-reports regarding everyday situations. The inventory includes 38 items that address different skills divided into six factors: Empathy (i.e., on observing that a friend is sad or having difficulty in school, the adolescent offers support or help); Self-control (when criticized by parents and teachers, the adolescent can calm 
down and control the irritation); Civility (when someone does something good, the adolescent can give praise and be thankful when receiving praise); Assertiveness (if the adolescent believes that something is wrong, even under peer pressure, the adolescent does not act as his or her friends wish); Affective Approach (when the adolescent wishes to establish a friendship, he or she invites the person to meet or to perform an activity together); Social Resourcefulness (the adolescent can make an oral group presentation at school on request). The participants responded to the items using a Likert scale that ranged from 0 (never) to 4 (always). A. Del Prette and Z. Del Prette (2009) administered the instrument to 1,172 adolescents of both genders and found satisfactory internal consistency ( $\alpha=.89$ for the total scale and .68 to .85 for the frequency factors).

The Social Support Appraisal (SS-A) Scale assesses the social support appraisals of adolescents regarding family, friends and teachers. The scale consists of 22 items arranged on a Likert scale that ranges from 1 (strongly disagree) to 6 (strongly agree) and grouped into three factors: social support appraisals from family (i.e., feels loved by the family), social support appraisals from friends (i.e., notices the affection of friends) and social support appraisals from teachers (i.e., trusts the teachers). Leme (2013) performed a validation of the scale (Social Support Appraisal - SSA, Antunes \& Fontaine, 2005) for Brazil for a sample of 477 adolescents between the ages of 13 to 17 years and observed good internal consistency for the SS-A factors (family: $\alpha=.89$, friends: $\alpha=.87$, teachers: $\alpha=.81$ ).

The Psychological Well-Being Scale (PWS) investigates the capabilities of the individual to face life's challenges from a perspective of positive psychological functioning (Ryff, 1989). In Brazil, the scale was adapted and validated by Machado, Bandeira and Pawlowski (2013). The scale consists of 36 items distributed among six factors: positive relations with others (i.e., has satisfying and intimate relationships with others), autonomy (i.e., is self-determined and resists pressure from others), environmental mastery (i.e., properly uses opportunities), personal growth (i.e., is open to new experiences), purpose in life (i.e., feels that past and present life have meaning) and self-acceptance (i.e., knows and accepts qualities and shortcomings). Each item is responded to on a Likert scale that ranges from 1 (strongly disagree) to 6 points (completely agree). Machado et al. (2013) applied the scale to 312 college students of both genders and found acceptable internal consistency rates (Cronbach's alpha), which ranged from .63 to .75 .

The Questionnaire on Family Character and Demographic Information was developed for this study to obtain social and demographic information, such as data on the adolescents and information on family configuration. The study also employed the Brazil Economic Classification Criterion Questionnaire (ABEP, 2011), which assesses the socioeconomic level and enables the stratification of families into five classes in order of decreasing purchasing power: $\mathrm{A}$ (A1 and $\mathrm{A} 2), \mathrm{B}$ (B1 and B2), C, D and $\mathrm{E}$.

\section{Procedure}

Data collection. After receiving the informed consent forms signed by the legal guardians of the students, data were collectively obtained in the classrooms at a time agreed beforehand with the teachers. At the beginning of each application (average duration: 70 minutes), the students were informed regarding the study objectives, the confidentiality of the collected data was assured and the voluntary nature of participation was reiterated.

Data analysis. Data analysis was performed using the Statistical Package for the Social Sciences for Windows software (SPSS, version 18.0). First, the differences related to the education level of the head of household, socioeconomic level (using one-way analysis of variance [ANOVA]) and the gender of the adolescents (using the chi-square test) were examined. Then, the correlations among the study variables were calculated (using Pearson's $r$ coefficient). To interpret the values of the correlation coefficients $(r)$, the classification proposed by Bryman and Cramer was used (2003): $<.20=$ very weak; $\geq .20$ and $<.40=$ weak; $\geq .40$ and $<.70=$ moderate; $\geq .70$ and $<.90=$ strong; $>.90=$ very strong. Finally, stepwise multiple linear regression analysis was performed. Prior to the multiple regression analysis, the assumptions of normality, independence and multicollinearity were tested and confirmed (Marôco, 2011). The psychological well-being of adolescents was considered to be the dependent variable (DV), whereas family configuration, the six factors of social skills and the social support appraisals from family, friends and teachers were considered to be the independent variables (IV). Two dummy variables were created to replace the non-metric IV family configuration (i.e., nuclear, separated and remarried). The significance level adopted for all of the tests was $p<.05$.

\section{Ethical Considerations}

The study was approved by the Human Research Ethics Committee of the Universidade Federal de São Carlos in accordance with Opinion no. 287/2011, CAAE: 0076.0.135.000-11. Student participation was voluntary and ratified by the Informed Consent Form, which was previously signed by the legal guardians of the participants.

\section{Results}

Comparative analysis indicated no difference between the types of family according to the gender of the adolescent $\left(\chi^{2}=3.18 ; p=.20\right)$, the education level of the head of household $(F(2.39)=0.40 ; p=.68)$ (which ranged from complete high school education to incomplete higher education) and the socioeconomic level $(F(2.43)=1.58$; 
$p=.21)$. With the exception of family type $(r=.03 ; p=.46)$, the results suggest a significant positive correlation, which was mostly weak, between the social skills variables empathy $(r=.46 ; p=.001)$, self-control $(r=.37 ; p=.001)$, civility $(r=.40 ; p=.001)$, assertiveness $(r=.30 ; p=.001)$, emotional approach $(r=.27 ; p=.001)$, social resourcefulness $(r=.37$; $p=.001)$ and social support appraisals from family $(r=.31$; $p=.001)$, friends $(r=.37 ; p=.001)$ and teachers $(r=.23$; $p=.001)$ with the psychological well-being of adolescents from different family configurations.

The results of the multiple linear regression analysis for the psychological well-being of adolescents from nuclear, separated and remarried families are presented in Table 1.

Table 1 shows a significant final model $(F(7.43)=39.10$; $p=.001)$ with seven predictor variables that explain $38 \%$ of the variance in the psychological well-being of the adolescents. The results suggest that the social skill empathy has greater weight in the prediction of the result and that the family configuration does not predict the psychological wellbeing of adolescents. The positive standardized regression coefficients $(\beta)$ values suggest that higher levels of the social skills empathy, self-control, civility, social resourcefulness and affective approach and higher levels of social support appraisals from friends and family contribute to the increased level of psychological well-being of adolescents from nuclear, separated and remarried families.

\section{Discussion}

According to the initial hypothesis, the results suggest that family type was not a significant predictor for the psychological well-being of adolescents. Similar results have been found by other studies that observed that family configuration does not affect the well-being of children (Adler-Baeder et al., 2010; Fernandes, 2007). The results of this study suggest that the circumstances that the families are experiencing, whether normative or not, can be addressed throughout the life of individuals in a more or less competent manner (Greeff \& Du Toit, 2009; Mota $\&$ Matos, 2011). Thus, the family transitions are not events that are associated with less adaptive pathways. On the contrary, these events depend on the complex interplay between internal and external personal resources available to the family members (Hetherington, 2003; Wallerstein et al., 2013). These resources idiosyncratically define the manner in which parents and children address not only the challenges but also the opportunities that underlie interpersonal relationships during the continuities and discontinuities of human development.

With the exception of assertiveness, all of the social skills included in the regression model (i.e., self-control, civility, social resourcefulness and affective approach) appeared to explain the psychological well-being of the adolescents, which is consistent with the results of other studies (Sá, 2012; Sarkova et al., 2013). These social skills can contribute to more affectionate, positive and reciprocal parent-child interactions that promote psychological well-being. However, they may impede the emergence of interpersonal relationships based on aggressiveness and/or passiveness. Among the social skills analyzed in this study, empathy seems to have a greater contribution to psychological well-being. Empathy is a social skill of great importance for adolescents from separated and remarried families. However, in addition, belonging to these family configurations may predispose an adolescent to develop it. The possession of this social skill can help the adolescent understand the behaviors and feelings of parents who dissolved their marriage and formed a new marital union help the adolescent cope with the reorganization of parental power and the coexistence with stepparents.

Although assertiveness was not a significant predictor of psychological well-being, this social skill is important not only for the well-being of any adolescent (Sarkova et al., 2013) but also for those from separated and remarried families. For example, learning to express feelings of anger and displeasure, asking for behavioral changes and negotiating conflicting interests can facilitate interpersonal relationships between the adolescent and the family members (such as grandparents, uncles/aunts and siblings) and with

Table 1

Predictor Variables of the Psychological Well-Being of Adolescents $(N=454)$

\begin{tabular}{|c|c|c|c|c|c|c|c|}
\hline Predictor Variables & Constant & $B$ & SE $B$ & $\beta$ & $95 \% \mathrm{CI}$ & $\Delta R^{2}$ & Total $R^{2}$ \\
\hline Empathy & $116.82 * *$ & .77 & .20 & .22 & {$[0.37 ; 1.17]$} & $.21 * *$ & .38 \\
\hline Support Appraisals from Friends & $92.62 * *$ & .63 & .14 & .19 & {$[0.35 ; 0.90]$} & $.09 * *$ & \\
\hline Self-control & $91.79 * *$ & .45 & .14 & .14 & {$[0.17 ; 0.72]$} & $.03 * *$ & \\
\hline Civility & $84.24 * *$ & .88 & .27 & .14 & {$[0.35 ; 1.40]$} & $.02 * *$ & \\
\hline Social resourcefulness & $82.91 * *$ & .74 & .28 & .12 & {$[0.19 ; 1.30]$} & $.01 * *$ & \\
\hline Support appraisals from family & $79.12 * *$ & .30 & .12 & .12 & {$[0.05 ; 0.53]$} & $.01 *$ & \\
\hline Affective approach & $77.77 * *$ & .40 & .20 & .08 & {$[0.01 ; 0.78]$} & $.01 *$ & \\
\hline
\end{tabular}

Note. $B=$ non-standardized regression coefficient; SE $B=$ standard error of the non-standardized regression coefficient; $\beta=$ standardized regression coefficient; $\mathrm{CI}=$ confidence interval; $\Delta R^{2}=$ sum of the adjusted determination coefficient; $R^{2}=$ adjusted determination coefficient. $* p<.05 . * * p<.01$. 
the individuals who became part of the family environment after the remarriage of parents (such as the stepfather, the stepmother and their children).

Studies conducted in the United States have demonstrated an increase in recent generations in the levels of assertiveness and other variables of personal agency (such as self-efficacy and resilience), whereas there has also been an increase in the levels of external locus of control, depression and anxiety and a decrease in the levels of concern for others and for social and public causes (Twenge, Campbell, \& Freeman, 2012). Thus, these results suggest that assertiveness is a social skill class that (at least among the young) can be interpreted to be less prosocial and less associated with personal wellbeing. However, the cultural and ecological specificity of the constructs and their respective operationalization does not enable an unambiguous reading of this result. However, the results suggest that special attention be paid in future studies to the reciprocal relationships between assertiveness on the one hand and other social skills and different dimensions of well-being on the other.

The results suggest that the social support appraisals from friends and family explain variations in the psychological well-being of adolescents. These results are supported by several studies that found a correlation between the identification by the adolescents of social support from family and friends and greater levels of well-being (Casas et al., 2007; Sarriera et al., 2012). Regarding family transitions, social support appraisals from friends may facilitate the emergence of adaptation processes if, for example, the adolescent is experiencing the separation and remarriage of parents (Greeff \& Du Toit, 2009). In this sense, the friends would be a source of emotional support that encourages adolescents to share their experiences and feelings and to learn to address conflict. Although the social support appraisal from teachers was not positively associated with the well-being of adolescents, interconnections of the school and family environments are inevitable (Leme, Del Prette, Koller, \& Del Prette, in press). It is possible that there is lower perception of social support from teachers, particularly regarding non-academic issues (Sterrett, Jones, McKee, \& Kincaid, 2011). In contrast, adolescents do not always share information regarding their personal lives with their teachers. Thus, the teachers are often unaware of familial disruptions in the lives of their students. However, the social support from teachers seems to function as a protective mechanism for adolescents who experience parental marital dissolution (Greeff \& Du Toit, 2009). Because the instrument contained items that referred to a generic teacher, a scale to assess support appraisals from a specific teacher could provide different results.

In agreement with other studies (Amparo, Galvão, Alves, Brasil, \& Koller, 2008; Camacho \& Matos, 2012), the results of this study suggest that in adolescence social support from family and friends interact and complement one another while jointly influencing the psychological well-being of adolescents. These results have important implications for the development of adolescents because the interactions in the family context enable the acquisition or development of certain social skills, whereas interpersonal relationships with friends present other demands and therefore encourage the development of other social skills (A. Del Prette \& Z. Del Prette, 2009; Tomé \& Matos, 2012). In sum, the psychological well-being of the adolescents was predicted by a combination of variables that explained approximately $38 \%$ of the variance of this construct, with the social skills and the social support appraisals working together to influence the well-being of adolescents.

In general, the influence of social skills and social support appraisals from family and friends on the psychological well-being of adolescents indicated that an understanding of adolescent development must always be contextualized while considering the particularities and idiosyncrasies of the relationships and the different contexts that can result in the manifestation of various behaviors, regardless of family configuration.

Regarding the limitations of this study, it should be emphasized that the study is primarily cross-sectional and correlational, which precludes causal explanations. Second, the social skills, social support appraisals and the psychological well-being were evaluated from the perspective of adolescents. The results might have been different if other informants, such as parents and teachers, were consulted. Although reasonable values have been found for the regression coefficients, a number of the possible predictors of the psychological well-being of the adolescents were selected based on the literature review. Thus, no conclusion can be drawn on the relative importance of the variables that relate to the family and school contexts. Future studies could include other variables and use those investigated in this study in interventions with adolescents who are experiencing difficulties in their adjustment to family transitions and include not only the adolescent but also other members of the family and the school. A longitudinal approach could be useful to assess changes and continuities in patterns of the relationships of adolescents with their fathers/mothers, peers and teachers.

\section{References}

Adler-Baeder, F., Russell, C., Kerpelman, J., Pittman, J., Ketring, S., Smith, T., ... Stringer, K. (2010). Thriving in stepfamilies: Exploring competence and well-being among African American youth. Journal of Adolescence Health, 46(4), 396-398. doi:10.1016/j.jadohealth.2009.10.014

Amato, P. R., \& Afifi, T. D. (2006). Feeling caught between parents: Adult children's relations with parents and subjective well-being. Journal of Marriage and Family, 68(1), 222-235. doi:10.1111/j.1741-3737.2006.00243.x 
Amato, P. R., \& Anthony, C. J. (2014). Estimating the effects of parental divorce and death with fixed effects models. Journal of Marriage and Family, 76(2), 370-386. doi:10.1111/jomf.12100

Anderson, E. R., \& Greene, S. M. (2013). Beyond divorce: Research on children in repartnered and remarried families. Family Court Review, 51(1), 119-130. doi:10.1111/fcre. 12013

Antunes, C., \& Fontaine, A. M. (2005). Percepção de apoio social na adolescência: Análise fatorial confirmatória da escola Social Support Appraisals. Paidéia (Ribeirão Preto), 15(32), 355-366. doi:10.1590/S0103-863X2005000300005

Amparo, D. M., Galvão, A. C. T., Alves, P. B., Brasil, K. T., \& Koller, S. H. (2008). Adolescentes e jovens em situação de risco psicossocial: Redes de apoio social e fatores pessoais de proteção. Estudos de Psicologia, 13(2), 165-174. doi:10.1590/S1413-294X2008000200009

Aragão, E. I. S., Vieira, S. S., Alves, M. G. G., \& Santos, A. F. (2009). Suporte social e estresse: Uma revisão de literatura. Psicologia em Foco, 2(1), 79-90.

Associação Brasileira de Empresas de Pesquisa. (2011). Critério de Classificação Econômica Brasil: Dados com base no levantamento socioeconômico 2009. Retrieved from http://www.abep.org/new/criterioBrasil.aspx

Bizarro, L. (2010). Adolescence psychological well-being: Effects of problems with parents. Annali di Congresso Internazionale Educazione Familiare e Servizi per L'Infanzia, 13, 1-11.

Bryman, A., \& Cramer, D. (2003). Análise de dados em ciências sociais: Introdução às técnicas utilizando o SPSS para Windows (D. Lopes, Trans., 3rd ed.). Oeiras, Portugal: Celta.

Camacho, I., \& Matos, M. G. (2012). Aventura social nas famílias. In M. G. Matos \& G. Tomé (Coords.), Aventura social: Promoção e competências e do capital social para um empreendedorismo com saúde na escola e na comunidade (pp. 126-139). Lisboa, Portugal: Placebo.

Cavanagh, S. E., Crissey, S. R., \& Raley, R. K. (2008). Family structure history and adolescent romance. Journal of Marriage and Family, 70(3), 698-714. doi:10.1111/j.1741-3737.2008.00515.x

Casas, F., Figuer, C., González, M., Malo, S., Alsinet, C., \& Subarroca, S. (2007). The well-being of 12 - to 16-year-old adolescents and their parents: Results from 1999 to 2003 Spanish samples. Social Indicators Research, 83(1), 87-115. doi:10.1007/s11205-006-9059-1

Del Prette, A., \& Del Prette, Z. A. P. (2009). Inventário de Habilidades Sociais para Adolescentes (IHSD-Del-Prette): Manual de aplicação, apuração e interpretação. São Paulo, SP: Casa do Psicólogo.

Del Prette, Z.A. P., \& Del Prette, A. (2010). Habilidades sociais e análise do comportamento: Proximidade histórica e atualidades. Perspectivas em Análise do Comportamento, 1(2), 104-115.
Falcone, E. M. O., Ferreira, M. C., Luz, R. C. M., Fernandes C. S., Faria C. A., D’Augustin, J. F., ... Pinho, V. D. (2008). Inventário de Empatia (IE): Desenvolvimento e validação de uma medida brasileira. Avaliação Psicológica, 7(3), 321-334.

Fernandes, H. M. G. (2007). O bem-estar psicológico em adolescentes: Uma abordagem centrada no florescimento humano (Unpublished doctoral dissertation). Universidade de Trás-os-Montes e Alto Douro, Vila Real, Portugal.

Friedlander, L. J., Connolly, J. A., Pepler, D. J., \& Craig, W. M. (2007). Biological, familial, and peer influences on dating in early adolescence. Archives of Sexual Behavior, 36(6), 821-830. doi:10.1007/s10508-006-9130-7

Gonçalves, T. R., Pawlowski, J., Bandeira, D. R., \& Piccinini, C. A. (2011). Avaliação do apoio social em estudos brasileiros: Aspectos conceituais e instrumentais. Ciência \& Saúde Coletiva, 16(3), 1755-1769. doi:10.1590/S1413-81232011000300012

Greeff, A. P., \& Du Toit, C. (2009). Resilience in remarriage families. The American Journal of Family Therapy, 37(2), 114-126. doi:10.1080/01926180802151919

Hamama, L., \& Ronen-Shenhav, A. (2012). Self-control, social support, and aggression among adolescents in divorced and two-parent families. Children and Youth Services Review, 34(5), 1042-1049. doi:10.1016/j.childyouth.2012.02.009

Hetherington, E. M. (2003). Intimate pathways: Changing patterns in close personal relationships across time. Family Relations: An Interdisciplinary Journal of Applied Family Studies, 52(4), 318-331. doi:10.1111/j.1741-3729.2003.00318.x

Ivanova, K., Mills, M., \& Veenstra, R. (2011). The initiation of dating in adolescence: The effect of parental divorce. The trails study. Journal of Research on Adolescence, 21(4), 769-775. doi:10.1111/j.1532-7795.2010.00734.x

Joronen, K., \& Astedt-Kurki, P. (2005). Familial contribution to adolescent subjective well-being. International Journal of Nursing Practice, 11(3), 125-133. doi:10.1111/j.1440-172X.2005.00509.x

Leme, V. B. R. (2013). Adolescentes de familias nucleares, monoparentais e recasadas: Relações entre práticas parentais, habilidades sociais, bem-estar psicológico e percepção de apoio social (Protocol No. 11/05321-4). São Paulo, SP: FAPESP. Unpublished Research Report.

Leme, V. B. R., Del Prette, Z. A. P., Koller, S. H., \& Del Prette, A. (in press). Habilidades sociais e o modelo bioecológico do desenvolvimento humano: Análise e perspectivas. Psicologia \& Sociedade.

Levin, K. A., Kirby, J., \& Currie, C. (2012). Adolescent risk behaviours and mealtime routines: Does family meal frequency alter the association between family structure and risk behaviour? Health Education Research, 27(1), 24-35. doi:10.1093/her/cyr084 
Machado, W. L., Bandeira, D. R., \& Pawlowski, J. (2013). Validação da Psychological Well-being Scale em uma amostra de estudantes universitários. Avaliação Psicológica, 12(2), 263-272.

Marôco, J. (2011). Análise estatística com o SPSS Statistics (5th ed.). Pêro Pinheiro, Portugal: ReportNumber.

Mota, C. P., \& Matos, P. M. (2011). Adolescência e conflitos parentais: Uma perspectiva de resiliência. In P. M. Matos, C. Duarte, \& M. E. Costa (Coords.), Famílias: Questões de desenvolvimento e intervenção (pp. 125-150). Porto, Portugal: LivPsic.

Musick, K., \& Meier, A. (2010). Are both parents always better than one? Parental conflict and young adult well-being. Social Science Research, 39(5), 814-830. doi:10.1016/j.ssresearch.2010.03.002

Nomaguchi, K. M. (2008). Gender, family structure, and adolescents' primary confidants. Journal of Marriage and Family, 70(5), 1213-1227. doi:10.1111/j.1741-3737.2008.00561.x

Oliveira, D., Siqueira, A. C., Dell'Aglio, D. D., \& Lopes, R. C. S. (2008). Impacto das configurações familiares no desenvolvimento de crianças e adolescentes: Uma revisão da produção científica. Interação em Psicologia, 12(1), 87-98. doi:10.5380\%2Fpsi.v12i1.9172

Pearson, J., Muller, C., \& Frisco, M. L. (2006). Parental involvement, family structure, and adolescent sexual decision making. Sociological Perspectives, 49(1), 67-90. doi:10.1525/sop.2006.49.1.67

Pérez Milena, A., Pérez Milena, R., Martínez Fernández, M. L., Leal Helmling, F. J., Mesa Gallardo, I., \& Jiménez Pulido, I. (2007). Estructura y funcionalidad de la familia durante la adolescencia: Relación con el apoyo social, el consumo de tóxicos y el malestar psíquico. Atención Primaria, 39(2), 61-65. doi:10.1157/13098670

Ruschena, E., Prior, M., Sanson, A., \& Smart, D. (2005). A longitudinal study adolescent adjustment following family transitions. Journal of Child Psychology and Psychiatry, 46(4), 353-363. doi:10.1111/j.1469-7610.2004.00369.x

Ryff, C. D. (1989). Happiness is everything, or is it? Explorations on the meaning of psychological wellbeing. Journal of Personality and Social Psychology, 57(6), 1069-1081. doi:10.1037/0022-3514.57.6.1069

Sá, E. M. M. (2012). Habilidades sociais, bem-estar psicológico e rendimento escolar (Unpublished doctoral dissertation). Universidade de Aveiro, Aveiro, Portugal.

Sarriera, J. C., Abs, D., Casas, F., \& Bedin, L. M. (2012). Relations between media, perceived social support and personal well-being in adolescence. Journal Social Indicators Research, 106(3), 545-561. doi:10.1007/s11205-011-9821-x
Sarkova, M., Bacikova-Sleskova, M., Orosova, O., Geckova, A. M., Katreniakova, Z., Klein, D., ... van Dijk, J. P. (2013). Associations between assertiveness, psychological well-being, and self-esteem in adolescents. Journal of Applied Social Psychology, 43(1), 147-154. doi:10.1111/j.1559-1816.2012.00988.x

Shin,S.H.,Choi,H.,Kim,M.J.,\&Kim,Y.H.(2010).Comparing adolescents' adjustment and family resilience in divorced families depending on the types of primary caregiver. Journal of Clinical Nursing, 19(11-12), 1695-1706. doi:10.1111/j.1365-2702.2009.03081.x

Sterrett, E. M., Jones, D. J., McKee, L. G., \& Kincaid, C. (2011). Supportive non-parental adults and adolescent psychosocial functioning: Using social support as a theoretical framework. American Journal of Community Psychology, 48(3-4), 284-295. doi:10.1007/s10464-011-9429-y

Tomcikova, Z., Geckova, A. M., Orosova, O., van Dijk, J. P., \& Reijneveld, S. A. (2009). Parental divorce and adolescent drunkenness: Role of socioeconomic position, psychological well-being and social support. European Addict Research, 15(4), 202-208. doi:10.1159/000231883

Tomé, G., \& Matos, M. G. (2012). Relação positiva com o grupo de pares na adolescência. In M. G. Matos \& G. Tomé (Coords.), Aventura social: Promoção e competências e do capital social para um empreendedorismo com saúde na escola e na comunidade (pp. 112-125). Lisboa, Portugal: Placebo.

Twenge, J. M., Campbell, W. K., \& Freeman, E. C. (2012). Generational differences in young adults' life goals, concern for others, and civic orientation, 1966-2009. Journal of Personality and Social Psychology, 102(5), 1045-1062. doi:10.1037/a0027408

Valle, G., \& Tillman, K. H. (2014). Childhood family structure and romantic relationships during the transition to adulthood. Journal of Family Issues, 35(1), 97-124. doi:10.1177/0192513X12463555

Vanassche, S., Sodermans, A. K., Matthijs, K., \& Swicegood, G. (2014). The effects of family relationships and parental role models on delinquency and alcohol use among Flemish adolescents. Journal of Child and Family Studies, 23(1), 128-143. doi:10.1007/s10826-012-9699-5

Vaux A., Phillips, J., Holly, L., Thomson, B., Williams, D., \& Stewart, D. (1986). The social support appraisals (SSA) scale: Studies of reliability and validity. American Journal of Community Psychology, 14(2), 195-219. doi:10.1007/BF00911821

Wagner, A., Tronco, C., \& Armani, A. B. (2011). Os desafios da família contemporânea: Revisitando conceitos. In A. Wagner (Org.), Desafios psicossociais da família contemporânea: Pesquisa e reflexões (pp. 19-35). Porto Alegre, RS: Artmed. 
Wallerstein, J., Lewis, J., \& Rosenthal, S. P. (2013). Mothers and their children after divorce: Report from a 25-year longitudinal study. Psychoanalytic Psychology, 30(2), 167-184. doi:10.1037/a0032511

Vanessa Barbosa Romera Leme is a Professor at the Universidade Salgado de Oliveira.

Zilda Aparecida Pereira Del Prette is a Professor at the Universidade Federal de São Carlos.

Susana Coimbra is a Professor at the Universidade do Porto.

Received: Feb. 21, 2014

1st Revision: June 5, 2014

2nd Revision: Aug. 21, 2014

Approved: Sep. 25, 2014

How to cite this article:

Leme, V. B. R., Del Prette, Z. A. P., \& Coimbra, S. (2015). Social skills, social support and well-being in adolescents of different family configurations. Paidéia (Ribeirão Preto), 25(60), 9-17. doi: 10.1590/1982-43272560201503 


\section{Erratum}

In the article "Social Skills, Social Support and Well-Being in Adolescents of Different Family Configurations" published in the journal Paidéia (Ribeirão Preto), 25(60), 9-17, on page 9, for:

"Zilda Aparecida Perreira Del Prette"

read:

"Zilda Aparecida Pereira Del Prette"

In the same article, on page 17, for:

"Zilda Aparecida Perreira Del Prette"

read:

“Zilda Aparecida Pereira Del Prette" 